Brit. F. vener. Dis. (1968), 44, 160.

\title{
ATTITUDES OF COLLEGE STUDENTS IN EAST AFRICA TO SEXUAL ACTIVITY AND VENEREAL DISEASE*
}

\author{
BY \\ O. P. ARYA AND F. J. BENNETT \\ College Health Service and Department of Preventive Medicine, \\ Makerere University Medical School, University of East Africa, Kampala, Uganda
}

Venereal disease is a major disease problem in University students in East Africa (Arya and Bennett, 1967), where about 25 per cent. are affected each year. It was apparent that a programme of health education was needed, though what should be taught was not clear. As some students do not become infected and others are infected repeatedly, it was thought that a study of the differences in behaviour, attitudes, and knowledge between these two groups might provide data as a starting point for discussion groups, and information on the aspects of the subject most in need of attention.

\section{Method}

Two samples of fifty cases were studied, the first comprising students who had had one or more attacks of venereal disease and the second a control group of fifty students with no history of infection. Only unmarried male African students who had completed at least one academic year in the college were selected. Cases and controls were taken as they reported at the College Health Service for any illness, when the student was informed of the study and invited to make an appointment for an interview in his own room in the hall of residence. There were no refusals. The interviews, each lasting about 11 hours, were all conducted by the same doctor who went through a set of 22 questions followed by a period for discussion. The opportunity was taken to correct any lack of knowledge or incorrect attitudes discovered during the interviews.

\section{Results}

The characteristics of the cases and controls are shown in Tables I to VI. The control group contained fewer young students and city dwellers, but these differences were not significant.

* Received for publication July 25, 1967.

TABLE I

AGE OF CASES AND CONTROLS

\begin{tabular}{l|c|c}
\multicolumn{1}{c|}{ Age Group (yrs) } & Cases & Controls \\
\hline Below 20 & 0 & 1 \\
$21-25$ & 37 & 29 \\
$26-30$ & 13 & 19 \\
Over 30 & 0 & 1 \\
\hline \multicolumn{1}{c|}{ Total } & 50 & 50 \\
\hline
\end{tabular}

TABLE II

YEAR OF ENTRY TO COLLEGE

\begin{tabular}{l|c|c}
\hline \multicolumn{1}{c|}{ Year } & Cases & Controls \\
\hline Before 1963 & 3 & 2 \\
1963 & 7 & 7 \\
1964 & 21 & 17 \\
1965 & 19 & 24 \\
\hline \multicolumn{1}{c|}{ Total } & 50 & 50 \\
\hline
\end{tabular}

TABLE III

FACULTY

\begin{tabular}{l|r|c}
\hline \multicolumn{1}{c|}{ Faculty } & Cases & Controls \\
\hline Agriculture & 5 & 4 \\
Arts & 23 & 20 \\
Education & 6 & 6 \\
Fine Art & 2 & 2 \\
Medicine & 4 & 3 \\
Science & 10 & 14 \\
Librarianship & 0 & 1 \\
\hline \multicolumn{1}{|c|}{ Total } & 50 & 50 \\
\hline
\end{tabular}

TABLE IV

RELIGION

\begin{tabular}{l|c|c|c}
\hline \multicolumn{1}{|c|}{ Religion } & Cases & Controls \\
\hline Christian & $\begin{array}{l}\text { Catholic } \\
\text { Protestant }\end{array}$ & 13 & 17 \\
\hline Islamic & 31 & 32 \\
\hline Nil & 5 & 0 \\
\hline \multicolumn{1}{c|}{ Total } & 1 & 1 \\
\hline
\end{tabular}

TABLE $\mathrm{V}$

HOME BACKGROUND

\begin{tabular}{c|c|c}
\hline \multicolumn{1}{c|}{ Background } & Cases & Controls \\
\hline Rural & 32 & 39 \\
Urban & 18 & 11 \\
\hline Total & 50 & 50 \\
\hline
\end{tabular}


TABLE VI

ETHNIC AND NATIONAL ORIGIN

\begin{tabular}{l|c|c}
\multicolumn{1}{c|}{ Ethnic Group } & Cases & Controls \\
\hline Ganda & 6 & 12 \\
Uganda Bantu-speaking & 17 & 15 \\
Non-Bantu & 7 & 10 \\
Kenya & 6 & 8 \\
Tanzania & 10 & 3 \\
Other & 4 & 2 \\
\hline \multicolumn{1}{c|}{ Total } & 50 & 50, \\
\hline
\end{tabular}

Information derived from answers to the questionnaire is classified under the following headings:

Attitude to Premarital Sexual Intercourse (Table VII)

There was no statistically significant difference between cases and controls in their attitude to premarital sexual intercourse. The reason given for approval in 73 per cent. was "to satisfy the sexual urge", which was further justified by such descriptions and phrases as "irresistible urges, necessary evil, sexual restlessness, for enjoyment, because one is sexually developed before marriage, because it is the only outlet for the unmarried". Approximately one-quarter of those approving thought that premarital sexual intercourse was necessary in order to find out what marriage entailed, to see if their sexual performance was adequate, to gain sexual practice, and to eliminate nervousness. They also approved of intercourse with the girls they intended to marry so that they could know each other better, ensure that there was no abnormality, and ensure sexual rapport. A small proportion approved because they had "a liberal attitude to sex and it is expected in a modern society".

TABLE VII

ATTITUDE TOWARDS

PREMARITAL SEXUAL INTERCOURSE

\begin{tabular}{l|c|c|c}
\hline \multicolumn{1}{c|}{ Attitude } & Cases & Controls & Total \\
\hline Approval & 28 & 24 & 52 \\
Disapproval & 17 & 23 & 40 \\
Ambivalent & 4 & 3 & 7 \\
No opinion & 1 & 0 & 1 \\
\hline \multicolumn{1}{c|}{ Total } & 50 & 50 & 100 \\
\hline
\end{tabular}

Reasons for disapproval were cultural, religious, and moral in most cases (slightly more of the controls gave religious reasons for disapproval). Surprisingly, only 25 per cent. of those disapproving gave the possibility of pregnancy or of contracting venereal disease as reasons, although at the time of interview all knew that these could be the consequences.

Four cases and three controls expressed a double standard, disapproving of intercourse with girls they would marry but approvingof it with other womenpreferably prostitutes or women outside their own ethnic group or village.

\section{Sexual Experience}

There were no differences between cases and controls in respect of age or education level when sexual experience started (Tables VIII and IX).

TABLE VIII

AGE AT WHICH SEXUAL EXPERIENCE BEGAN

\begin{tabular}{l|c|c|c}
\hline \multicolumn{1}{c|}{ Age (yrs) } & Cases & Controls & Total \\
\cline { 1 - 2 } Under 10 & 4 & 4 & 8 \\
$11-15$ & 8 & 6 & 14 \\
$16-20$ & 28 & 29 & 57 \\
Above 20 & 10 & 8 & 18 \\
No sexual intercourse yet & 0 & 3 & 3 \\
\hline \multicolumn{1}{c|}{ Total } & 50 & 50 & 100 \\
\hline
\end{tabular}

TABLE IX

EDUCATIONAL LEVEL

\begin{tabular}{l|c|c}
\hline \multicolumn{1}{c|}{ Educational Level } & Cases & Controls \\
\hline Primary & 7 & 8 \\
Junior Secondary & 10 & 9 \\
Senior Secondary & 27 & 24 \\
College & 2 & 3 \\
At work after school & 2 & 1 \\
Not known & 2 & 2 \\
No sexual intercourse yet & 0 & 3 \\
\hline
\end{tabular}

At least 8 per cent. of those interviewed began their sexual careers before the age of 10 and only a minority were still inexperienced by the age of 20 years. The number of female partners (Table X) showed that cases were more promiscuous than controls, the differences being highly significant at the $0 \cdot 1$ per cent. level.

TABLE $\mathrm{X}$

No. OF FEMALE PARTNERS EXPERIENCED

\begin{tabular}{l|c|c|c}
\hline No. of Female Partners & Cases & Controls & Total \\
\hline None & 0 & 3 & 3 \\
to 5 & 11 & 27 & 38 \\
More than 5 & 39 & 20 & 59 \\
\hline \multicolumn{1}{c|}{ Total } & 50 & 50 & 100 \\
\hline
\end{tabular}

Similarly, a question on the number of sexual partners experienced since entering College showed that the cases had had significantly $(0 \cdot 1$ per cent. level) more partners; 26 controls had no female contacts in the College town, whereas almost half the cases had had more than five. When the numbers of contacts in the last 12 months was examined, the cases still showed significantly greater promiscuity than the controls.

The frequency of sexual intercourse in the last 12 months in the College town shows a difference 
significant at the $0 \cdot 1$ per cent. level. (Table XI).

TABLE XI

FREQUENCY OF INTERCOURSE IN COLLEGE TOWN IN LAST 12 MONTHS

\begin{tabular}{l|c|c}
\hline Frequency in last 12 mths & Cases & Controls \\
\hline None & 9 & 28 \\
1to 5 than 5 times & 10 & 8 \\
More than & 31 & 14 \\
\hline Total & 50 & 50 \\
\hline
\end{tabular}

A similar difference was also noted in the frequency of intercourse related to place of residence during the vacation.

\section{Awareness of the Possible Consequences of Sexual Intercourse at the Time of the First Experience}

There was no statistically significant difference between cases and controls in their awareness of the risk of venereal disease or pregnancy resulting from sexual activity. Approximately 30 per cent. had not known that pregnancy could follow a single contact and 20 per cent. were unaware of the risk of venereal disease when they first started having intercourse, though by the time of interview all had acquired this knowledge (Table XII).

TABLE XII

KNOWLEDGE OF VENEREAL DISEASE

\begin{tabular}{l|r|r}
\hline $\begin{array}{c}\text { Age at which Knowledge of } \\
\text { Venereal Disease was first acquired } \\
\text { (yrs) }\end{array}$ & Cases & Controls \\
\hline Under 10 & 5 & 5 \\
$11-15$ & 14 & 28 \\
$16-20$ & 5 & 14 \\
Above 20 & 50 & 50 \\
\hline \multicolumn{1}{c|}{ Total } & 5 & 5 \\
\hline
\end{tabular}

Students who had never contracted venereal disease had learned of the risk at a significantly ( 5 per cent. level) earlier age than those who had become infected.

Information about venereal disease (Table XIII) had usually been acquired from friends or by overhearing gossip or conversation, though some students learned from several other sources. Parents and teachers appeared to play little part in educating young people in these matters.

TABLE XIII

SOURCE OF KNOWLEDGE

(Some multiple answers)

\begin{tabular}{l|c|c}
\hline \multicolumn{1}{c|}{$\begin{array}{c}\text { Source of Knowledge of } \\
\text { Venereal Disease }\end{array}$} & Cases & Controls \\
\hline Parents & 1 & 5 \\
Teachers & 8 & 6 \\
Books & 8 & 11 \\
Doctor & 2 & 1 \\
Friends or others & 33 & 35 \\
\hline
\end{tabular}

Venereal disease was considered to be serious by 48 cases and 44 controls and only a few thought it to be just a mild ordinary disease. Two considered gonorrhoea as "ordinary" but syphilis as "serious". There was no statistically significant difference between the two groups in their attitude towards the degree of danger from venereal disease. In keeping with their view of venereal disease as a serious matter, the majority in each group were anxious and felt guilty after intercourse. Most, except those treated and cured rapidly, felt that it interfered with their studies. These feelings, however, had little deterrent effect, as 37 of the cases had had venereal disease more than once, eight more than three times. Most of the knowledge acquired was limited to gonorrhoea. Syphilis was mentioned by few and none knew about any other venereal diseases. Most of the complications mentioned (which included sterility, impotence, destruction of the genitals, and urethral stricture) were thought to be due to gonorrhoea and were related to the reproductive system. 25 per cent. of those interviewed did not know of any complications, controls and cases being equally ignorant.

\section{Choice of Sexual Partner}

Significantly more of the controls had intercourse with girl friends only, whereas more of the cases also slept with barmaids, nightclub girls, prostitutes, and pick-ups (Table XIV). Out of the 25 controls who had had intercourse only with their girl friends, 24 intended marriage in due course (even though not all approved of premarital intercourse). Five of the eight cases who had had intercourse with girl friends only intended to marry them.

TABLE XIV

TYPE OF PARTNER

\begin{tabular}{l|c|c}
\hline \multicolumn{1}{c|}{ Type of Partner } & Cases & Controls \\
\hline Casual only & 8 & 4 \\
Friends only & 8 & 25 \\
Both Casual and Friends & 34 & 18 \\
None & 0 & 3 \\
\hline
\end{tabular}

83 per cent. of all those interviewed thought it was bad to change partners frequently; there was no difference between the two groups. Changing partners "frequently" probably meant weekly or monthly, because almost 60 per cent. of those disapproving had already had sexual intercourse with more than five women.

80 per cent. of the total (with no difference between cases and controls) preferred single girls. A few who had had intercourse with married women gave the following reasons: being in love with her before her 
marriage, being a neighbour, or being unlikely to be blamed if she became pregnant. None considered the consequences of their adultery to her marriage.

The criteria for choosing a sexual partner were many-that the girl should be clean, socially charming, beautiful, educated, small in size, or with a sense of humour. Some preferred schoolgirls or nurses because of a common belief that they would be free from venereal disease (the results show these beliefs are not justified). Some avoided schoolgirls because of the higher penalties if pregnancy ensued.

Avoidance of prostitutes, barmaids, and nightclub girls was mentioned by eighteen controls as against nine cases. Similarly, more controls mentioned that they would like to know the girl and her family background well before having intercourse with her. Fourteen controls and only five cases considered the general behaviour and character of the girl. On the whole it appeared that those who had not contracted venereal disease were more careful in their selection of sexual partners than those who had; a quarter of the cases had no criteria for selection at all.

Probably the best indication of the relationship between student and partner is whether there was any payment for sexual intercourse. Table XV shows that significantly more $(0 \cdot 1$ per cent. level) cases than controls paid for their pleasure, since the controls often had more permanent relationships.

TABLE XV

FORM OF PAYMENT

\begin{tabular}{l|c|c}
\hline \multicolumn{1}{c|}{ Form of Payment } & Cases & Controls \\
\hline Cash & 6 & 0 \\
Kind & 24 & 14 \\
Cash/Kind/Support & 6 & 1 \\
No payment & 14 & 32 \\
No partner & 0 & 3 \\
\hline \multicolumn{1}{c|}{ Total } & 50 & 50 \\
\hline
\end{tabular}

\section{Environmental and Other Factors related to}

Sexual Intercourse

Only three students related the sexual urge to periods of examination stress and in general there was little insight into physical and emotional reactions to study or examination stress.

Most of those who had had intercourse in the previous 12 months had had it at no fixed time. 30 per cent. preferred it as a weekend or vacation activity.

The cases frequented bars and nightclubs significantly ( 0.5 per cent. level) more frequently than the controls; only four cases never went to such places compared with eighteen controls. At least 31 cases of venereal disease were contracted from a partner picked up in a bar or nightclub. The reasons given for not going to nightclubs were: not being able to afford it, fearing venereal disease, not liking the atmosphere, or fearing to be robbed on returning to the College late at night. Alcohol was a factor in this series, as 43 cases sometimes or always drank alcohol before intercourse as compared with 26 controls, and 21 controls but only seven cases never drank before intercourse. These differences are significant at the 0.5 per cent. level. A significantly greater number of cases were sometimes or always intoxicated at the time of intercourse and these particular episodes were often those leading to venereal disease. Invariably the girl also had taken alcohol.

\section{Effect of Venereal Disease on Attitude to Sex}

22 cases said that after the first attack of venereal disease they had become more careful and selective and avoided nightclub girls and strangers.

Twenty reported a temporary change in attitude until they had forgotten about the disease or until their judgement was altered by alcohol. One mentioned that he enforced a period of abstinence on himself as a punishment. Two thought that they had made a permanent decision to avoid intercourse until marriage.

Six, who were the most promiscuous, said that venereal disease made no difference and they had all suffered repeated re-infections.

\section{Knowledge of Methods of Contraception}

There was no difference between the two groups in knowledge of methods of contraception. Most knew about contraceptive sheaths, about half had heard of anovulatory pills, very few had heard of other contraceptive devices, and very few knew of the safe period. Spermicidal preparations and coitus interruptus were mentioned by some. Six cases and seven controls did not know of any methods of contraception.

\section{Attitudes to taking Contraceptive Precautions}

Here again there was no real difference between the two groups. Very few used condoms, and these mainly with girl friends to prevent pregnancy rather than disease. Twelve cases and 22 controls used the safe period with their girl friends only and they relied on the girl's statement as to when it was safe. No individual practised a method of contraception on every occasion, and half of the total took no precautions at all. 
The more responsible attitude of the controls towards pregnancy can be seen in Table XVI, the difference between cases and controls being highly significant.

TABLE XVI

ATTITUDE TOWARDS PREGNANCY OR ILLEGITIMATE BIRTHS

\begin{tabular}{l|c|c}
\multicolumn{1}{c|}{ Attitude } & Cases & Controls \\
\hline Never considered it or do not care & 25 & 9 \\
Hope it will not occur & 4 & 4 \\
Will get married and & 13 & 33 \\
accept the responsibility & 4 & 3 \\
Abortion & 4 & 1 \\
Will pay fine or damages & & \\
\hline
\end{tabular}

Knowledge of Prophylactic Measures against

Venereal Disease (Table XVII)

There was no significant difference between the groups, but it is clear that many knew of no measure that could protect them from acquiring venereal disease : $\mathbf{4 2}$ cases and $\mathbf{4 5}$ controls took no precautions, eight cases sometimes used sheaths or drugs, and five controls sometimes used sheaths.

\section{TABLE XVII}

KNOWLEDGE OF PROPHYLACTIC MEASURES AGAINST VENEREAL DISEASE, (Some multiple answers)

\begin{tabular}{l|r|c}
\hline Known Prophylactic Method & Cases & Controls \\
\hline Sheath & 23 & 13 \\
Drugs & 8 & 4 \\
Abstinence & 7 & 7 \\
Washing after contact & 0 & 1 \\
Avoidance of prostitutes & 1 & 7 \\
Urinating after contact & 1 & 0 \\
Keeping to one girl friend & 0 & 2 \\
None & 18 & 22 \\
\hline
\end{tabular}

The sheath, as mentioned earlier, was used mainly to protect against pregnancy and then only with girl friends. It was unpopular because both the students and their partners thought that it interfered with the enjoyment of sex. Other reasons for not using it were: that it could come off, that it was good for only one orgasm when it was usual to have several, that they preferred to trust the partner, that it was forgotten under the influence of alcohol, that it was expensive, that its use was not known.

The only drug mentioned for prophylactic use was one that could be obtained in capsule form. Some knew it by name as Tetracycline. These capsules could apparently be obtained from friends or saved from a previous course of treatment or even bought on the black market. One or two capsules only were thought to be effective.

\section{Discussion}

The control group consisting of students who had never had venereal disease was difficult to find, and the fifty interviewed probably represented a considerable proportion of their total in the College. In retrospect it would have been better to have centred this study in the students who had not had venereal disease and to have drawn the controls from the greater population of those who had been infected. There were no statistically significant differences between the characteristics of the cases and controls, so that it may not appear in this study that religion, ethnic group, domicile, age, or faculty are important protective factors, although in another study (Arya and Bennett, 1967) it was found that ethnic group, national origin, and faculty did contribute towards differing incidence rates.

The extent of sexual experience was significantly different in the two groups-the cases having had more experience with a greater number of women, more frequent intercourse, and more intercourse in the College town. The causes of this more extensive sexual activity need investigation-are they personality factors or biological ones related to earlier maturity, or are they socio-cultural ? Probably the urge to have new partners is more relevant to the spread of venereal disease than the urge to have frequent intercourse, and thus the psycho-social rather than the biological concomitants of promiscuity need more study.

Cases differed from controls in that they had more often taken alcohol or become intoxicated before intercourse. This was probably related to the fact that they also went to bars and nightclubs more frequently and took barmaids, nightclub girls, and prostitutes as their sexual partners more often than the controls. The controls appear as a more responsible and selective group with a different pattern of leisure pursuits. Their sexual intercourse is part of a social relationship and is carried on more often with a steady partner whom they are prepared to marry if she becomes pregnant, although some use sheaths to prevent this occurrence. The cases more often have a casual sexual relationship which is paid for and in which they can ignore the possibility of pregnancy; whether they prefer this situation or are unable to establish the same pattern as the controls is not clear.

In this study certain factors appeared to be related to a high risk of venereal disease, and conversely certain students seemed to carry their protective attributes of knowledge, attitudes, or behaviour with them all the way through College. This is supported by the fact that, in a 6-month follow-up of all those interviewed, nineteen cases 
had further attacks of venereal disease but only one control had a first attack.

Surprisingly, the questions which revealed no difference between the two groups were those relating to attitude towards premarital intercourse and age at the time of first sexual experience. This indicates that those who do not contract venereal disease have no severe, perhaps religious, disapproval of intercourse and are not men with less sex drive.

This study revealed a serious degree of ignorance, for which parents or teachers must be held responsible. The early age at which sexual experience begins indicates that it is parents and teachers who should properly give such knowledge; the fact that the controls acquired some knowledge of venereal disease earlier than the cases further emphasizes the need for early education about sex and venereal disease. The students were particularly ignorant about methods of contraception and the risk of venereal disease and its complications. The misuse of tetracycline as a prophylactic is also evidence of faulty knowledge.

The acquisition of venereal disease and its treatment by the College Health Service (where counselling and discussion always accompany drug therapy) does not appear to reduce the chances of re-infection. It is extremely difficult to change attitudes towards sex and venereal disease based on personality factors already acquired by the time the students enter College. Some of those who have had repeated attacks have been receiving psychiatric treatment for psychoneurotic depression or inadequate personalities.

Losb (1960) favoured a realistic attitude in health education. If this is adopted then the sheath should be advocated more as a prophylactic measure, though this would not meet with acceptance in all religious groups. Abstinence is so rare that it need not be considered as a realistic solution and education should aim rather at the wise selection of partners, preferably as an extension of a social relationship carrying responsibilities. In the words of Cochran (1964) "the College student must learn emphatically that sex involves love, marriage, and the responsibilities that go with these relationships, and he must believe what he has learned and act upon it".

This teaching should be given in the school and home before entrance to the university, but students can be given factual information on the high incidence of venereal infection in the town, the clinical appearance and complications of the various diseases, the dangers of associating with prostitutes and casual pick-ups, and the close connexion between alcohol and the risk of venereal disease.
The students' own suggestions often related to treating the local prostitutes or a particular partner if they thought her suitable to return to. This is a very reasonable step to take but difficult to implement in practice, and all the College has been able to do is to treat wives if necessary and to advise or arrange for the treatment of other known contacts. The problem of prevention extends beyond the university itself into the behaviour of a much wider élite group.

\section{Summary}

Attitudes to venereal disease and sexual activity were investigated in fifty African male students with venereal disease and in fifty controls with no history of venereal disease.

The cases differed significantly from the controls in having more frequent intercourse, more partners, and a higher intake of alcohol before intercourse; they frequented nightclubs and bars more often and also took prostitutes and casual acquaintances as partners more frequently.

The controls more often had intercourse with steady girl friends whom they would marry if pregnancy ensued.

There was little difference between the groups in their attitude to premarital intercourse and in their age at the time of their first sexual experience.

On the whole, the students had insufficient knowledge of venereal disease, but the controls had acquired their information earlier than the cases. Methods of contraception (other than the sheath) were not widely known. Parents and teachers had apparently contributed little to the students' education regarding sex and venereal disease.

Personality factors appeared to be important and some of the cases were receiving treatment for psychoneuroses or inadequate personalities.

The authors suggest that, in the College environment in East Africa, students should be given factual information on the high incidence of venereal disease, the clinical picture and complications, the risk of intercourse with prostitutes and pick-ups, and the association between alcohol and the risk of acquiring venereal disease. The need for a wise selection of partners and for sexual activity to form part of a social relationship carrying major responsibilities should be taught at an early age in home and school.

\section{REFERENCES}

Arya, O. P., and Bennett, F. J. (1967). Brit. F. vener. Dis., 43, 275.

Cochran, R. B. (1964). F. Amer. Coll. Hlth Ass., 13, 187.

Loeb, M. B. (1960). Brit. F. vener. Dis., 36, 191. 
L'attitude des étudiants de l'Afrique Orientale envers les rapports sexuels et les maladies vénériennes

\section{RÉsumé}

L'attitude envers les rapports sexuels et les maladies vénériennes a été etudiée chez 50 étudiants africains atteints de maladie vénérienne et chez 50 contrôles qui ne donnaient pas d'historique de maladie vénérienne.

Les cas différaient d'une façon significative des contrôles en ayant eu des rapports sexuels plus fréquents, des partenaires plus nombreuses et aussi ils avaient fait une consommation de boissons alcooliques plus marquée avant les rapports sexuels; ils fréquentaient des boîtes de nuit et des bars plus souvent et aussi acceptaient plus souvent les prostituées et des connaissances fortuites comme partenaires.

Les contrôles, le plus souvent, avaient des rapports sexuels avec des amies regulières qu'ils épouseraient si la grossesse survenait.

Il y avait très peu de différence entre les deux groupes quant à leur attitude envers les rapports sexuels avant le mariage et aussi quant à leur âge au moment de leur première expérience du rapport sexuel.
En somme, les étudiants avaient une connaissance insuffisante des maladies vénériennes mais les contrôles avaient aquis leurs renseignements plus tôt que les autres. Les méthodes de contraception (autre que le condom) n'étaient pas très connues. Les parents et les professeurs n'avaient, apparemment, contribué que très peu à l'éducation des étudiants au sujet de la vie sexuelle et des maladies vénériennes.

Les facteurs concernant la personnalité des étudiants semblaient être importants et quelques uns parmi les cas recevaient un traitement pour des psychonévroses ou pour des caractères faibles.

Les auteurs suggèrent que, dans l'ambiance des collèges en Afrique Orientale, les étudiants devraient recevoir des renseignements précis au sujet de la forte incidence des maladies vénériennes, des signes cliniques et les complications, des risques encourus pendant les rapports sexuels avec des prostituées ou avec des rencontres fortuites, et de l'association entre l'alcool et le risque de contracter les maladies vénériennes.

On devrait enseigner de bonne heure à la maison et à l'école la nécessité d'une sélection sage du choix des partenaires et aussi que les rapports sexuels donnent lieu à des relations sociales comportant de grandes responsabilités. 